\title{
HUBUNGAN KECERDASAN EMOSIONAL DENGAN INTERAKSI SOSIAL SISWA KELAS XI MAN 5 SLEMAN TAHUN PELAJARAN 2019/2020
}

\author{
Sri Maryuni Rahma Putri ${ }^{1}$ \\ Dra. Hj. Nur Wahyumiani, $\mathbf{M A}^{2}$ \\ Program Sarjana Bimbingan dan Konseling \\ Universitas PGRI Yogyakarta \\ Email: srimaryunirahmaputri@gmail.com
}

\begin{abstract}
Abstrak
Tujuan penelitian ini adalah untuk mengetahui hubungan antara kecerdasan emosional dengan interaksi sosial siswa kelas XI MAN 5 Sleman tahun pelajaran 2019/2020. Populasi penelitian ini adalah siswa kelas XI di MAN 5 Sleman tahun pelajaran 2019/2020 yang berjumlah 224 siswa. Pengambilan sampel dalam penelitian ini menggunakan teknik quota cluster random sampling yaitu sebesar 25\% dari jumlah populasi, sehingga diperoleh 56 siswa. Metode pengumpulan data dalam penelitian ini menggunakan angket. Teknik analisis data menggunakan statistik korelasi product moment. Hasil penelitian menunjukkan bahwa ada hubungan positif yang signifikan antara kecerdasan emosional dengan interaksi sosial siswa kelas XI MAN 5 Sleman tahun pelajaran 2019/2020. Dibuktikan dengan nilai $\mathrm{R}_{\mathrm{xy}}(0,513)$, pada taraf signifikan $0,000<0,05$. Dengan demikian semakin tinggi kecerdasan emosional siswa maka semakin tinggi interaksi sosial siswa, sebaliknya semakin rendah kecerdasan emosional siswa maka semakin rendah interaksi sosial siswa.
\end{abstract}

Kata kunci: kecerdasan emosional, interaksi sosial

\begin{abstract}
The purpose of this study was to determine the Corellation Of Emotional Intelligence With Social Interaction Of Class XI MAN 5 Sleman Students in 2019/2020. The population of this research is class XI students at MAN 5 Sleman in the academic year 2019/2020 with a total of 224 students. Sampling in this study uses a quota cluster random sampling technique that is equal to $25 \%$ of the population, so as to obtain 56 students. Data collection methods in this study using a validated questionnaire. Data analysis techniques using statistics with a product moment correlation. The results showed that there was a significant positive correlation of emotional intelligence with social interaction in class XI MAN 5 Sleman in 2019/2020. The results of the product moment correlation test found the value of $R_{x y}(0,513)>R_{\text {tabel }}(0,259)$, with a significant level of $0.000<0.05$. Thus the higher the emotional intelligence of students, the higher the social interaction of students, conversely the lower the emotional intelligence of students, the lower the social interaction of studentss.
\end{abstract}

Keywords: emotional intelligence, social interaction

\section{Info Artikel}

Diterima Februari 2020, disetujui Maret 2020, diterbitkan Juni 2020 


\section{PENDAHULUAN}

Kurikulum 2013 menuntut guru mampu menjadi kunci untuk mengembangkan potensi dan karakter peserta didik. Karakter peserta didik berkembang berdasarkan potensi yang dibawa sejak lahir atau yang dikenal sebagai karakter dasar yang bersifat biologis. Karakter adalah keseluruhan nilai-nilai, pemikiran, perkataan, perilaku atau perbuatan yang telah membentuk diri seseorang. Dengan demikian, karakter dapat disebut sebagai jati diri seseorang yang telah terbentuk dalam proses kehidupan yang berupa pola pikir, sikap dan perilaku. Karakter dapat dibentuk melalui pendidikan. Menurut Zubaedi (Agustini dkk, 2019:133) pendidikan karakter adalah usaha yang sungguh-sungguh untuk memahami, membentuk dan memupuk nilai-nilai etika, baik untuk diri sendiri maupun untuk semua warga masyarakat atau warga negara secara keseluruhan.

Guru bimbingan dan konseling berperan penting mengembangkan karakter peserta didik dengan membantu memahami, peduli, dan berbuat atau bertindak berdasarkan nilainilai dan etika. Pendidikan karakter merupakan pengintegrasian antara kecerdasan, kepribadian, dan akhlak mulia. Penerapan pendidikan karakter secara sistematis dan berkelanjutan, peserta didik akan menjadi cerdas emosinya dalam mempertajam serta memperkuat perasaan moralnya, sehingga ia akan mampu bertindak dengan benar. Kecerdasan emosional berperan penting dalam mempersiapkan peserta didik menyongsong masa depan, dengan kecerdasan emosional peserta didik dapat berhasil dalam menghadapi segala macam tantangan, termasuk tantangan untuk berhasil secara akademis. Menurut Daniel Goleman (Agustini dkk, 2019:133) kecerdasan emosional atau emotional intellegence merupakan kemampuan mengenali perasaan diri sendiri serta perasaan orang lain, kemampuan memotivasi diri sendiri, dan kemampuan mengelola emosi dengan baik pada diri sendiri serta dalam berhubungan dengan orang lain.

Kecerdasan emosional pada peserta didik masa kini perlu dikembangkan, karena banyak dijumpai peserta didik yang begitu cemerlang prestasi akademiknya namun tidak dapat mengelola emosinya, seperti mudah marah, angkuh dan sombong. Kurangnya pemahaman peserta didik terhadap kecerdasan emosional membuat peserta didik tidak mampu mengendalikan emosinya dan tidak dapat menyesuaikan dirinya dengan situasi atau masalah yang sedang dihadapi. Kecerdasan emosional sangat diperlukan dalam diri individu agar keberadaan individu lebih bermakna di tengah masyarakat sekitar. 
Daniel Goleman (Samsunuwiyatu Mar'at, 2015:170-172), mengklasifikasikan kecerdasan emosional terdapat lima komponen penting, yaitu: mengenali emosi, mengelola emosi, motivasi diri sendiri, berempati dengan orang lain, dan membina hubungan. Kelima komponen tersebut dapat dipahami bahwa kecerdasan emosi sangat dibutuhkan manusia dalam mencapai kesuksesan, baik dibidang sosial, akademis, dan karir. Fitriyani (Agustini dkk, 2019:134) mengemukakan kecerdasan emosional adalah suatu jenis kecerdasan yang dimiliki oleh seseorang yang mengacu pada pemusatan perhatian dalam mengenali, memahami, merasakan, mengelola, memotivasi diri sendiri dan orang lain serta dapat mengaplikasikan kemampuan tersebut dalam kehidupan pribadi dan sosial.

Kemampuan mengelola emosi dalam berhubungan dengan orang lain akan mempengaruhi adanya interaksi sosial. Menurut Sujarwanto (Agustini dkk, 2019:135) proses interaksi sosial akan akan menghasilkan dua bentuk, yaitu proses asiosiatif dan disosiatif. Bentuk interaksi sosial asosiatif merupakan bentuk interaksi yang mengarah pada keharmonisan hubungan sedangan bentuk proses disosiatif mengarah pada ketidak harmonisan bahkan sampai pada perpecahan.

Peserta didik dalam pemenuhan kebutuhan hidup tidak terlepas dari hubungan sosial dengan orang lain. Peserta didik berinteraksi dengan individu baik secara langsung atau tatap muka maupun secara tidak langsung. Peserta didik yang berinteraksi sosial dengan baik biasanya dapat mengatasi berbagai persoalan didalam pergaulan seperti tidak mengalami kesulitan untuk menjalani hubungan dengan teman baru, berkomunikasi secara efektif dengan orang lain, dan dapat mengakhiri pembicaraan tanpa mengecewakan atau menyakiti orang lain.

Cerdas secara emosi berarti memiliki aspek-aspek kecerdasan emosional yang mencakup kesadaran diri, motivasi diri, empati, mengelola emosi dan membina hubungan. Seseorang yang mampu mengelola emosi dengan baik, mengenali emosi orang lain, manajemen diri, dan berempati berpengaruh dalam proses berhubungan dengan orang lain. Dengan demikian individu yang mampu mengelola emosinya dengan baik akan mampu menyesuaikan diri terhadap lingkungan sosialnya. Keberhasilan individu dalam meniti kehidupan masa kini hingga masa yang akan datang dipengaruhi oleh salah satu faktor yaitu kecerdasan. Kecerdasan intelektual saja tidak cukup dan harus diimbangi dengan kecerdasan emosional. 
Hasil observasi serta wawancara dengan guru bimbingan dan konseling Madrasah Aliyah Negeri 5 Sleman diperoleh keterangan bahwa ada beberapa peserta didik yang cenderung pesimis, takut dan memiliki rasa benci berhubungan sosial dengan orang lain. Berdasarkan uraian tersebut, peneliti tertarik untuk melakukan penelitian dengan judul "Hubungan Antara Kecerdasan Emosional Dengan Interaksi Sosial Siswa Kelas XI Madrasah Aliyah Negeri 5 Sleman Tahun Pelajaran 2019/2020”.

\section{METODE PENELITIAN}

Jenis pendekatan yang digunakan dalam penelitian ini adalah pendekatan kuantitatif. Populasi yang menjadi sasaran adalah seluruh siswa kelas XI MAN 5 Sleman. Adapun jumlah populasi penelitian yaitu sebanyak 224 siswa yang terdiri dari siswa kelas XI Agama, XI MIPA 1, XI MIPA 2, XI MIPA 3, XI IIS 1, XI IIS 2, dan XI IIS 3. Namun demikian yang dijadikan subyek penelitian adalah berupa sampel, yaitu sebagian siswa untuk mewakili keseluruhan siswa tersebut. Pengambilan sampel dalam penelitian ini menggunakan teknik quota cluster random sampling yaitu sebesar $25 \%$ dari populasi, sehingga diperoleh 56 siswa. Metode pengumpulan data dalam penelitian ini dengan menggunakan angket. Teknik analisis data menggunakan statistik korelasi product moment. Perhitungan korelasi product moment dilakukan dengan bantuan program SPSS versi 16.0.

\section{HASIL DAN PEMBAHASAN}

\section{Deskripsi Data}

Data mengenai kecerdasan emosional siswa kelas XI MAN 5 Sleman diperoleh menggunakan instrument berupa angket tertutup sebanyak 20 item pernyataan. Pengkategorian skor kecerdasan emosional dapat dilihat pada tabel berikut :

Tabel 3.1

Tabel Pengkategorian Variabel Kecerdasan Emosional

\begin{tabular}{cccc}
\hline Interval & Kategori & Frekuensi & Persentase \\
\hline $20 \leq \mathrm{X}<40$ & Rendah & 0 & 0 \\
$40 \leq \mathrm{X}<60$ & Sedang & 33 & $58,93 \%$ \\
$60 \leq \mathrm{X}<80$ & Tinggi & 23 & $41,07 \%$ \\
& Jumlah & 56 & $100 \%$ \\
\hline
\end{tabular}


Berdasarkan tabel 3.1 dapat dinyatakan bahwa data kecerdasan emosional meliputi 0\% berada pada kategori rendah, 58,93\% berada pada kategori sedang dan 41,07\% berada pada kategori tinggi. Dengan demikian dapat disimpulkan bahwa data kecerdasan emosional siswa kelas XI MAN 5 Sleman Tahun Pelajaran 2019/2020 cenderung berkategori sedang. Dari data tersebut dapat dilihat bentuk grafik sebagai berikut :

Grafik 3.1

Grafik Kecerdasan Emosional

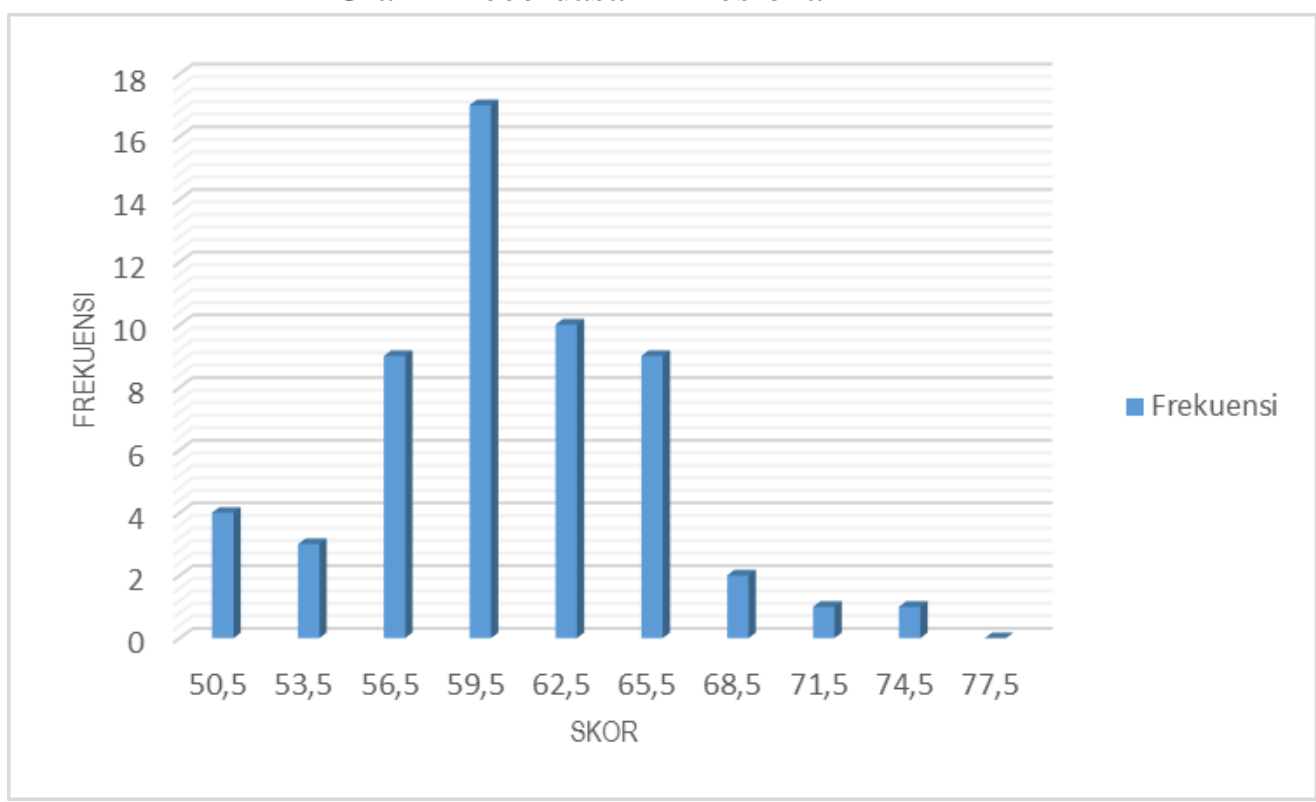

Berdasarkan grafik data kecerdasan emosional dapat diketahui bahwa frekuensi nilai terbanyak terdapat pada kelas interval ke-4.Selanjutnya dapat dilihat data berikut ini tentang tingkat kategori interaksi sosial siswa kelas XI MAN 5 Sleman Tahun Pelajaran 2019/2020 berikut :

Tabel 3.2

Tabel Pengkategorian Variabel Interaksi Sosial

\begin{tabular}{cccc}
\hline Interval & Kategori & Frekuensi & Persentase \\
\hline $20 \leq \mathrm{X}<40$ & Rendah & 0 & 0 \\
$40 \leq \mathrm{X}<60$ & Sedang & 43 & $76,78 \%$ \\
$60 \leq \mathrm{X}<80$ & Tinggi & 13 & $23,71 \%$ \\
& Jumlah & 56 & $100 \%$ \\
\hline
\end{tabular}

Berdasarkan tabel 3.2 dapat dinyatakan bahwa data interaksi sosial siswa meliputi $0 \%$ berada pada kategori rendah, $76,78 \%$ berada pada kategori sedang dan $23,71 \%$ berada pada kategori tinggi. Dengan demikian dapat disimpulkan bahwa data kecerdasan emosional siswa kelas XI MAN 5 Sleman Tahun Pelajaran 2019/2020 cenderung berkategori sedang. 
Dari data tersebut dapat dilihat bentuk grafik sebagai berikut : 


\section{Grafik 3.2}

Grafik Data Interaksi Sosial

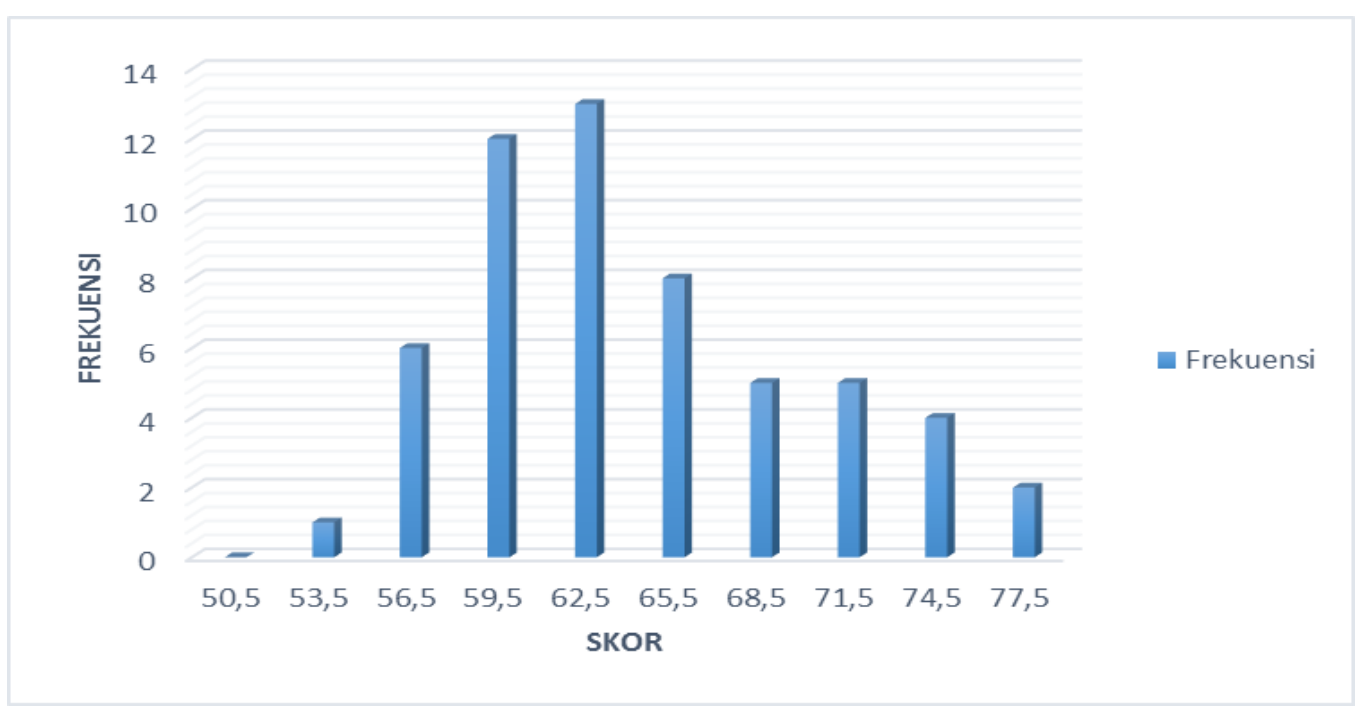

Berdasarkan histogram tentang data interaksi sosial dapat diketahui bahwa frekuensi nilai terbanyak terdapat pada kelas interval ke-5.

\section{Persyaratan Analisis Data}

1. Uji Normalitas

a) Hasil uji normalitas variabel kecerdasan emosional

Hasil uji normalitas pada sebaran variabel kecerdasan emosional siswa diperoleh nilai Kolmogorov-Smirnov sebesar 0,692 dengan $p(0,724)>\alpha(0,05)$, yang menunjukkan bahwa sebaran data pada variabel kecerdasan emosional adalah berdistribusi normal.

b) Hasil uji normalitas variabel interaksi sosial

Hasil uji normalitas pada sebaran variabel interaksi sosial diperoleh nilai Kolmogorov-Smirnov sebesar 0,990 dengan $p(0,281)>\alpha(0,05)$, yang menunjukkan bahwa sebaran data pada variabel interaksi sosial adalah berdistribusi normal.

2. Uji Linieritas

Hasil uji linieritas hubungan kecerdasan emosional (X) dengan interaksi sosial (Y) diperoleh nilai signifikan deviation from liniarity 0,711 atau >0,05. Hal ini menunjukkan bahwa hubungan kecerdasan emosional dengan interaksi sosial bersifat linier. 


\section{Hasil Analisis Data}

Setelah dilakukan uji prasyarat dan diketahui data berdistribusi normal, dilanjutkan uji hipotesis guna mengetahui adanya korelasi antar variabel. Uji hipotesis yang dilakukan dengan menggunakan teknik analisis korelasi product moment. Berdasarkan hasil analisis korelasi product moment diketahui ada hubungan positif dan signifikan antara kecerdasan emosional dengan interaksi sosial yang dibuktikan dengan Rxy adalah sebesar 0,513, dengan Sig. sebesar 0,000. Hasil ini menunjukkan bahwa nilai Rxy $(0,513)>$ Rtabel $(0,259)$. Dengan demikian alternative hypothesis (Ha) penelitian yang berbunyi "Ada hubungan antara kecerdasan emosional dengan interaksi sosial siswa kelas XI MAN 5 Sleman tahun pelajaran 2019/2020" adalah diterima, sehingga teruji kebenarannya. Sedangkan H(0) yang berbunyi "Tidak ada hubungan antara kecerdasan emosional terhadap interaksi sosial siswa kelas XI MAN 5 Sleman tahun pelajaran 2019/2020” dinyatakan ditolak.

\section{KESIMPULAN}

Data dalam penelitian ini dapat disimpulkan, ada hubungan yang positif dan signifikan antara kecerdasan emosional dengan interaksi sosial siswa kelas XI MAN 5 Sleman tahun pelajaran 2019/2020, artinya semakin tinggi kecerdasan emosional pada siswa maka semakin tinggi interaksi sosial siswa, sebaliknya semakin rendah kecerdasan emosional siswa maka semakin rendah interaksi sosial siswa.

\section{DAFTAR PUSTAKA}

Agustini, N. K. (2019). Korelasi Antara Kecerdasan Emosional dengan Interaksi Sosial Siswa Kelas V SD Gugus VI Pangeran Diponegoro Denpasar Barat. Universitas Pendidikan Ganesha.

Akbar, H. U. \& P. S. (2011). Metodologi Penelitian Sosial. Jakarta: PT Bumi Aksara.

Arifin, B. S. dan. (2005). Psikologi Sosial. Bandung:Remaja Rosda.

Arikunto, S. (2013). Prosedur Penelitian suatu Pendekatan Praktik. Yogyakarta: Rineka Cipta.

Bambang, S. (2015). Psikologi Sosial. Bandung: CV.Pustaka Setia.

Bungin, B. (2011). Penelitian Kualitatif. Jakarta: Kencana Pradana Media Group.

Casmini. (2007). Emotional Parenting. Yogyakarta: Pilar Media. 
Fadila, A. (2017). Hubungan Kecerdasan Emosi Dengan Interaksi Sosial Peserta Didik Kelas VI MI Ismaria Al-Qur'aniyyah Rajabasa Bandar Lampung Tahun Ajaran 2017/2018. Universitas Islam Negeri Raden Intan, 1-5.

Goleman, D. (2007). Kecerdasan Emosional. Jakarta: PT Gramedia Pustaka Utama.

Mar'at, S. (2015). Psikologi Perkembangan. Bandung: PT Remaja Rosdakarya.

Murni. (2015). Korelasi Antara Kecerdasan Emosional Dengan Interaksi Sosial Siswa Kelas VII MTS N 2 Pontianak. Universitas Tanjungpura Pontianak.

Purwito, A. W. A. (2018). Hubungan Kecerdasan Emosional Terhadap Penyesuaian Sosial Siswa Boarding School Pondok Pesantren Mujjaddadiyah Kota Madiun. Jurnal Empati:Universitas Diponegoro, 7, 328-333.

Uno, H. B. (2006). Orientasi Baru Dalam Psikologi Pembelajaran. Jakarta: PT Bumi Aksara.

Sujarweni, W. V. (2019). SPSS Untuk Penelitian. Yogyakarta: Pustaka Baru Press.

Soekanto, S. (2016). Sosiologi Suatu Pengantar. Jakarta:PT.Raja Grafindo. 